\title{
POMEGRANATE EXTRACTS ON LARVAL INHIBITION OF Haemonchus spp AND Cooperia spp OBTAINED FROM CATTLE
}

\author{
EXTRATOS DE ROMÃ SOBRE INIBIÇÃO LARVAL DE Haemonchus spp E Cooperia \\ spp PROVENIENTES DE BOVINOS
}

\section{Carolina dos ANJOS ${ }^{1}$; Bruno Toledo SILVA ${ }^{1}$; Luciane HOLSBACK Silveira Fertonani ${ }^{2}$; Camile Sanches SILVA ${ }^{1}$; Leopoldo Sussumu MATSUMOTO ${ }^{2}$; Regildo Márcio Gonçalves da SILVA $^{3}$; Erika Cosendey Toledo de MELLO-PEIXOTO ${ }^{2 *}$.}

1. Médico Veterinário do Centro de Ciências Agrárias, Universidade Estadual do Norte do Paraná - UENP, Campus, Bandeirantes, PR, Brasil; 2. Professor, Doutor, Medicina Veterinária e Agronomia do Centro de Ciências Agrárias - UENP, Bandeirantes, PR, Brasil; 3. Doutor, Faculdade de Ciências e Letras de Assis, Laboratório de Fitoterápicos - UNESP, Assis, SP, Brasil. emellopeixoto@uenp.edu.br; regildos@yahoo.com.br

\begin{abstract}
Consumers increasingly demand natural food and absent of toxic waste and medicated. The aim of this study was to evaluate the aqueous extract of dried and in natura stem from pomegranate on the larval inhibition of Haemonchus spp. and Cooperia spp. obtained from cattle. Dried and in natura aqueous extract from pomegranate stem (AEPS), negative control (autoclaved distilled water) and positive control (levamisole hydrochloride $0.05 \mathrm{mg} / \mathrm{mL}$ ) were evaluated. Four $\mathrm{mL}$ of each treatment were used, and the results were evaluated in triplicate by egg counts per gram of feces (EPG), larval culture and counting of the larvae. The mean of the larvae that developed per gram of feces was submitted to logarithimic transformation log. $(X+10)$. The EPG had an average value of 3.620 eggs, identified in larval culture from Haemonchus spp. and Cooperia spp. Dried AEPS presented, by the reduction of larvae, effectiveness of 92.29\% for Haemonchus spp. and $96.97 \%$ for Cooperia spp. In natura, this extract showed $80 \%$ of efficacy against Cooperia larvae, being considered moderately effective; however, for Haemonchus spp. this extract was not effective. These results are specially important for organic and agroecological systems of production, that not allow the use of chemical parasiticides. In conclusion, the use of dried AEPS showed potential anthelmintic and may represent important natural therapeutic option.
\end{abstract}

KEYWORDS: Agroecology. Medicinal Plants. Punica granatum Linn. Worm.

\section{INTRODUCTION}

Recent surveys point out that Brazil seems to be the largest beef exporter and the sixth largest milk producer (FAO, 2010). However, higher rates of productivity should only be achieved by an efficient parasiticide control.

Gastrointestinal nematode parasitism remains one of the main threats that affect the livestock. These losses are related to poor feed conversion, low weight gain and reduced production of beef or milk and could compromising the animal welfare. These factors provide a strong impetus for the current research on alternative solutions to minimize this problem.

The helminthosis are especially prevalent in development countries, due to the poor practices and inadequate management. The treatment is usually performed using chemically synthesized drugs which have favored the helminth resistance, as well as eliminating residues in the environment (SOUZA et al., 2008; LIMA et al., 2010).

The development of anthelmintic resistance has motivated the search for alternative treatment strategies to parasite control, including the use of herbal medicines (VIEIRA, 2008). Thus, investigations of natural bioactive compounds represent potential sources to control animal health and food security, reducing the amount and frequency of the use of chemicals products.

Representing a sustainable alternative, the use of medicinal plants, including their antiparasitic properties, have increased as reported in several studies in the field of veterinary medicine (CEZAR et al., 2008; NASCIMENTO et al., 2009; JOSHI et al., 2011; BATATINHA et al., 2011). The search for organic foods has expanded around the world, becoming an important consumer market. This fact has encouraged the farmers, especially in agroexporters countries, adopting sustainable technologies for productive resources, aiming to accord these consumers. In Brazil, the search for organic products has grown around $10 \%$ annually. Consumers are increasingly demanding healthier foods, produced from healthy animals and free of drug residues, from animals reared in systems that promote animal welfare, and which are sustainable and environmentally correct (D'ALMEIDA, 2005; MEDEIROS et al., 2011). 
The phytotherapy can be employed as an effective method in the management of gastrointestinal parasites, however studies involving herbal medicine in veterinary medicine still seems to be scarce. The pomegranate, Punica granatum Linn. (Punicaceae), is a deciduous shrub or small tree commonly cultivated worldwide in tropical and subtropical climates. The pomegranate tree can be extremely long lived (around 100 years old) and could be found throughout Brazil, although in small amounts. Their leaves are glossy and lance shaped, while the bark turns gray as the tree ages. The edible fruit is a large, globose berry, red-green or violet when ripe. It presents numerous angular seeds, covered by a thick skin, pulpy, with sweet taste that is slightly acidic, with their edible pulp, tasty and refresher (GOMES, 2007).

Healthy benefits of pomegranates have largely been attributed to their antibacterial and antiinflammatory properties. Their main phytochemicals compounds are alkaloids (pelletierine, isopeletierine, methilpeletierine), tannins, phenolic compounds (anthocyanins, quercetin, phenolic acids), flavonoids, ascorbic acid, conjugated fatty acid and ursolic acid (LANSKY; NEWMANN, 2007). Otero and Hidalgo (2004) reported that tannins may exert direct anti-parasitic properties by reducing the fecundity of female nematodes, or indirectly, by increasing the immune response to protect the dietary protein from rumenal degradation, increasing their availability in the large intestine (KETZIS, 2006). The in vitro anthelmintic activity of tannins was characterized by reduced hatch, development, motility of larvae (JOSHI et al., 2011) and adults. In vivo, they cause reductions in EPG (MAX et al., 2009; JOSHI et al, 2011.) and parasitic infection (MINHO et al., 2008; MAX et al., 2009). The tannins are not absorbed by the gastrointestinal tract of small ruminants, occurs disposal in feces and it reduces the pasture contamination (MUPEYO et al., 2011).

The tannins anthelmintic efficacy can also be influenced by the developmental stage of the parasite (HOSTE et al., 2006; BRUNET et al., 2008). The tannins affect the larval establishment (L3) and consequently block the infection. When the host is infected with adults, the function of nematode reproductive changes, reducing the EPG and pasture contamination (MARTÍNEZ-ORTÍZDE-MONTELLAN et al., 2010; JOSHI et al., 2011). These effects cause significant prospects for the control of nematodes by consumption of tanninipherous plants (OLIVEIRA et al., 2011). Therefore, the pomegranate has gained renewed interest as potential anti-parasitic due to their main component, the tannins. The great variability observed in relation to the anthelmintic activity of tannins effects in ruminants determines important perspectives for the control of nematodes and drugresistant populations to most of the anthelmintic drugs available. Thus, the present study aimed to determine the efficacy, in vitro, of the aqueous extract of pomegranate's stem bark, on larvae of Haemonchus spp. and Cooperia spp. from cattle.

\section{MATERIAL AND METHODS}

For preparation of the aqueous extract of pomegranate's stem bark, the plant material was collected on September 2011 at Bandeirantes - PR. Plants were harvested at the end of the morning, with temperatures about $25{ }^{\circ} \mathrm{C}$ and $80 \%$ of relative humidity.

In the Essential Oils \& Biotherapics laboratory from North of Paraná State University, the material was peeled, macerated and packed in craft paper bag. The drying was performed in a forced air incubator at $60{ }^{\circ} \mathrm{C}$ until the pomegranate stems reach a constant weight, obtaining the dried extract after 72 hours. Obtaining of the in natura extract did not considered this drying process.

To prepare the aqueous extract, $50 \mathrm{~g}$ of plant material were weighed on an analytical balance and immersed in $300 \mathrm{~mL}$ of autoclaved distilled water, thus were obtained the concentration of $12.5 \%$ $(\mathrm{w} / \mathrm{v})$.

The boiling was proceeded in water bath at $70{ }^{\circ} \mathrm{C}$ for 60 minutes and subsequent filtration was made using hydrophilic cotton. The extract was placed in amber sterile bottle and stored frozen in a freezer at $-20^{\circ} \mathrm{C}$ (JARDINI et al., 2007).

To determine the antioxidant activity (AA\%), total phenol and flavonoids, the extracts were referred to the Phytoterapic Laboratory of the Department of Biotechnology, from Paulista State University - UNESP, Assis. After lyophilization, the extracts were diluted at concentrations of $25,50,75$, $100,250,500$ and $1000 \mu \mathrm{g} / \mathrm{mL}$ and evaluated in triplicate.

The antioxidant activity of the extracts was determined by the donor ability of $\mathrm{H}^{+}$to the stable radical DPPH (2, 2-diphenyl-1-picrylhydrazyl), according to the in vitro methodology proposed by Blois (1958). The DPPH assay method is based on the reduction of DPPH, a stable free radical, from violet to yellow color. The test is sensitive enough to detect low concentrations of active ingredients (MANIAN et al., 2008), and the result can be viewed by the discoloration degree of the reagent after 30 minutes required for the reaction to reach a 
plateau, beyond the low value of $\mathrm{IC}_{50}$; in other words, the ability of the extract to inhibit $50 \%$ of the stem oxidation (DI MAMBRO; FONSECA, 2005). It was used $1 \mathrm{~mL}$ of acetate buffer solution $(\mathrm{pH} 5.5$ and $100 \mathrm{mM}$ ), $1.25 \mathrm{~mL}$ of ethanol PA, $250 \mu \mathrm{L}$ of DPPH solution $(250 \mu \mathrm{M})$ and $50 \mathrm{~mL}$ of the samples. The DPPH shows maximum absorbance at $517 \mathrm{~nm}$, which decreases in the presence of $\mathrm{H}^{+}$donor molecules, indicated by the violet color changes to yellow. The extract reacts with the DPPH radical in low light environment, and then is subjected to ultraviolet visible spectrophotometer (UV-Vis) at a wavelength of $517 \mathrm{~nm}$ (BRAND-WILLIAMS et al., 1995). The calculation of the antioxidant activity was performed according to the formula: Antioxidant Activity $(\%)=\left[\left(A_{\text {control }}-A_{\text {sample }}\right) / A_{\text {control }}\right]$ * 100, where $A_{\text {sample }}$ is the absorbance of the samples after 30 minutes and $A_{\text {control }}$ is the absorbance of DPPH; both at $517 \mathrm{~nm}$.

For the total phenols determination, the method used was Folin-Ciocalteu, using gallic acid as standard to comparison. To each $0.5 \mathrm{~mL}$ of the extract was added $5 \mathrm{~mL}$ of distilled water and 0.25 $\mathrm{mL}$ of Folin-Ciocalteu reagent (molybdate, tungstate and phosphoric acid). After 3 minutes, was added $1 \mathrm{~mL}$ of saturated $\mathrm{Na}_{2} \mathrm{CO}_{3}$ at $10 \%$, and the mixture was stored for one hour. The absorbance was measured at $725 \mathrm{~nm}$ using a UV-Vis spectrophotometer. The results were expressed as milligrams of gallic acid per gram of extract. Gallic acid is a precursor of several types of phenolic compounds and has a simple structure, being considered the standard substance.

The determination of total flavonoids of the extract was determined by UV-Vis spectrophotometer. Samples were prepared according to the Zhishen et al. (1999) methodology, based on the complexation of flavonoids with $\mathrm{AlCl}_{3}$, causing displacement of the absorption bands to longer wavelengths. A $250 \mu \mathrm{L}$ aliquot of the extracts concentrations that was above mentioned was added to $1.25 \mathrm{~mL}$ of distilled water and $75 \mu \mathrm{L}$ of a $\mathrm{NaNO}_{2}$ solution at $5 \%$. After 6 minutes, $150 \mu \mathrm{L}$ solution $\mathrm{AlCl}_{3} / \mathrm{H}_{2} \mathrm{O}$ at $10 \%$ was added. After 5 minutes, 0.5 $\mathrm{mL}$ of $1 \mathrm{M} \mathrm{NaOH}$ solution was added, and the total volume completed with $2.5 \mathrm{~mL}$ of distilled water. The samples were vortexed and the absorbance measured at $510 \mathrm{~nm}$. The results were expressed in milligrams of rutin per gram of extract. The rutin, as the quercetin, presents the flavonoids basic structure and can be used as an indirect indicator of flavonoids.

Tannins content of the extract was estimated by following the method as described by Fagbemi et al. (2005). The extract $(1 \mathrm{~mL})$ was mixed with
Folin- Ciacolteau's reagent $(0.5 \mathrm{~mL})$, followed by the addition of saturated $\mathrm{Na}_{2} \mathrm{CO}_{3}$ solution $(1 \mathrm{~mL})$ and distilled water $(8 \mathrm{~mL})$. The reaction mixture was allowed to stand for $30 \mathrm{~min}$ at room temperature. The supernatant was obtained by centrifugation and absorbance was recorded at 725 $\mathrm{nm}$ using UV-Visible Spectrophotometer. Tannins content was calculated as mg tannic acid equivalent from a linear regression equation obtained from a calibration curve $\left(\mathrm{R}^{2}=0.99304\right)$ : Abs725nm $K$ $0,0696 \kappa[\mathrm{TA}](\mathrm{mg})$ where $[\mathrm{TA}](\mathrm{mg})$ is the concentration of tannic acid taken as standard.

The feces were obtained from eight female cross-bred calves, three months old, that were never subjected to anthelmintic treatment before. These animals came from a Dairy farm located at Paraguaçu Paulista/SP. Feces were collected directly from the rectum, stored in plastic bags and transported in cool boxes at approximately $4{ }^{\circ} \mathrm{C}$.

At the Laboratory of Parasitology from UENP, the egg counts per gram of feces (EPG) were performed, according to the methodology of Gordon and Whitlock (1939), and larval culture by the technique described by Roberts and $\mathrm{O}$ 'Sullivan (1950) modified. It was used $4 \mathrm{~g}$ of feces, $8 \mathrm{~g}$ of sterile pine sawdust, and $4 \mathrm{~mL}$ of the respective treatments, as the dried aqueous extract from pomegranate stem (AEPS), in natura AEPS, Levamisole $(0.05 \mathrm{mg} / \mathrm{mL})$ as positive control and autoclaved distilled water (as negative control). The

larval culture were performed in triplicate and coded, to the experiment be performed blind. They were incubated for ten days in a Biochemical Oxygen Demand (BOD) micro processed incubator, at the temperature of $28^{\circ} \mathrm{C}$.

The larvae were collected according to the methodology described by Roberts and O'Sullivan (1950), placed in conical centrifuge tube and subjected to cooling. The content obtained from larval culture was measured. Then, counting and identification of the larvae was performed in $50 \mu \mathrm{L}$ of the solution by optical microscopy, following the criteria of Keith (1953). The total number of larvae was calculated based on the total volume of the larvae solution to each treatment (UENO; GONÇALVES, 1998).

To obtain the value of the larvae developed per gram of feces (LDPG), the total number of larvae observed in each treatment was divided by four (assuming that $4 \mathrm{~g}$ of feces used). The percentage of reduction in LDPG in each extract was determined by reducing the count of larvae in feces (RCLF) compared to the negative control 
group by the formula: \% efficacy $=[1-(\mathrm{LDPG}$ mean in the treated group/ LDPG mean in the control group)] $\mathrm{x} 100$. The effectiveness was classified as highly effective (> 98\%), effective (98$90 \%)$, moderately effective $(89-80 \%)$ and insufficiently effective $(<80 \%)$, as established by Wood et al. (1995).

For statistical analysis, the LDPG mean was transformed in logarithmic, $\log (x+10)$. It was used a completely randomized design, analysis of variance and Tukey's test at 5\% significance level, by GraphPrism 5 program.

\section{RESULTS}

At the moment before the treatments, the EPG presents a mean value of 3,620 Strongylid-type eggs, representing massive infection (UENO; GONÇALVES, 1998). After using treatments, the number of LDPG of Haemonchus spp and Cooperia spp was lower for dried AEPS treatment, compared with the other extracts (Table 1). Regarding the results for the Haemonchus spp, any treatment showed difference when compared to the negative control.

Table 1. Average developed larvae per gram of feces (LDPG) transformed to Log $(X+10)$, the dried and in natura aqueous extract of pomegranate stem treatments (AEPS), distilled water and levamisole.

\begin{tabular}{lllll}
\hline TREATMENTS & $\begin{array}{l}\text { LDPG } \\
(\text { Log.) }\end{array}$ & Haemonchus & $\begin{array}{l}\text { LDPG } \\
(\text { Log.) }\end{array}$ & $\begin{array}{l}\text { Cooperia } \\
\text { (Log.) }\end{array}$ \\
\hline Dried AEPS & $0.20^{\mathrm{b}}$ & $1.39^{\text {b.c }}$ & $1.41^{\text {b.c }}$ \\
In natura AEPS & $1.21^{\text {a.b }}$ & $2.36^{\text {a.c }}$ & $2.42^{\text {a.c }}$ \\
Distilled water & $1.31^{\text {a.b }}$ & $3.07^{\text {a }}$ & $3.09^{\text {a }}$ \\
Levamisole & $0.33^{\text {a.b }}$ & $0.81^{\mathrm{b}}$ & $0.96^{\mathrm{b}}$ \\
\hline
\end{tabular}

Means followed by the same lower case letter(s) in the column do not differ significantly between each other at $5 \%$ level of probability by the Tukey test.

The effectiveness of the treatments could be analyzed according to the values supported by the Ministry of Agriculture, Livestock and Food Supply, in the recommendations contained in
Ordinance $\mathrm{n}^{\circ} 48$, on 12 May 1997. Thus, the dried AEPS was effective for the helminths assessed (Table 2) in this study.

Table 2. Percentage reduction of developed larvae per gram of feces (effectiveness) regarding the treatment of dried and in natura aqueous extract of pomegranate stem (AEPS), and levamisole.

\begin{tabular}{llll}
\hline TREATMENTS & \% Haemonchus & \% Cooperia & \% Total of Larvae \\
\hline Dried AEPS & 92.29 & 96.97 & 96.84 \\
In natura AEPS & 42.20 & 80.24 & 79.19 \\
Levamisole & 88.87 & 99.34 & 99.05 \\
\hline
\end{tabular}

Concerning to the physico-chemical analyzes, dried AEPS showed antioxidant activity from the concentration of $50 \mu \mathrm{g} / \mathrm{mL}$, with values corresponding to $2.89 \%$, reaching $68.41 \%$ at the concentration of $1000 \mathrm{mg} / \mathrm{mL}$.

Total phenol analysis presented $0.15 \mathrm{mg}$ of gallic acid/g of extract to $100 \mu \mathrm{g} / \mathrm{mL}$, and $0.37 \mathrm{mg}$ of gallic acid/g of extract for concentration of 1000 $\mu \mathrm{g} / \mathrm{mL}$. For the content of flavonoids, only the concentration of $1000 \mu \mathrm{g} / \mathrm{mL}$ showed values corresponding to $0.06 \mathrm{mg}$ of rutin/g of extract. In relation to the tannins content ( $\mathrm{mg} / \mathrm{g}$ dry weight), the AEPS presented 278,88 $\mathrm{mg} / \mathrm{g}$ which represented $27,88 \%$.

\section{DISCUSSION}

Turning to the levamisole, the low efficacy could be explained by the parasitic resistance to the pharmacological basis of this drug. According to Sczesny-Moraes et al. (2010), these resistances could be observed in the genera Haemonchus, Trichostrongylus, Cooperia and Oesophagostomum, in greater or lesser intensity, being the genera Haemonchus the most resistant.

The interest in antioxidants is present, mainly due to the effects of free radicals in the organism, which are produced from the oxidations, essential for aerobic life. Free radicals react with DNA and RNA, proteins and other oxidizable substances, promoting damage that could contribute to the cellular aging (PEREIRA et al., 2009). 
Perhaps the presence of other substances alkaloids present in the extracts may have been responsible for the antioxidant activity observed. Noda et al. (2002) evaluated acetone extract of $P$. granatum and pointed the contribution of three anthocyanins (delphinidin, cyanidin and pelargonidine) for the antioxidant activity. They noted that these anthocyanins inactivate the superoxide and inhibit the lipid peroxidation induced by $\mathrm{H}_{2} \mathrm{O}_{2}$.

Phenolic compounds are one of the main groups of molecules that act as antioxidants, being found in pomegranate extracts. The flavonoids, one of the most diverse and widespread phytochemicals groups, are probably the most important natural compounds, possessing a wide spectrum of chemical products and biological activity, including free radical scavenging properties (PEDRIALLI et al., 2010).

Lorenzi and Matos (2002) performed phytochemical analysis of the pomegranate tree, recording the presence of up to $28 \%$ of gallic tannins in the stem bark and fruit, and to a lesser extent, in leaves. Hoste et al. (2006), have assimilated the tannins anthelmintic activity to reduce hatching, larval development and motility, and decreased in adults' motility. Additionally, they reported the larval unsheathing, which was also observed in this present study.

Corroborating to these results, Mupeyo et al. (2011) also noted the influence of tannins on the larval hatching and development of nematodes. Also considered that, as tannins are not absorbed by the small ruminants' gastrointestinal tract, your elimination occurs by feces and could reduce pasture contamination. According Athanasiadou et al. (2001) the tannins are complexed with abomasum protein, being unavailable to exert abomasal anthelmintic activity. Therefore, further studies must be performed to evaluate the in vivo efficacy in the control of Haemonchus spp, characterized by parasitize the abomasum.

One of the problems in the phytoterapics research is the variation of the herbal active principle in plants depending on the season, stage of development, geographical location, collection and preparation, causing considerable changes and compromises the quality and quantity of these ingredients (ROZWALKA et al., 2008). Thus, in vitro studies are justified as preliminary essential processes to the study of new natural parasiticidal drugs with potential for clinical application. Natural bioactive substances can be too much important for the control of animal health and food safety, and could help to decrease the amount or frequency of use the chemical products. This aspect is particularly important for agroecological, organic or biological-dynamic production systems, which the use of chemical drugs is considered a limiting factor.

\section{CONCLUSION}

The use of aqueous extract of the pomegranate's stem bark, mainly the dried extract, revealed in vitro efficacy in the control of bovine worms showing up a potential anthelmintic to contribute as adjunctive therapy to control this bovine disorder.

\section{ACKNOWNLEDGMENT}

We thank the National Council for Scientific and Technological Development and the Brazilian Ministries (Ministry of Science, Technology and Innovation, Ministry of Agriculture, Livestock and Supply, Ministry of Agrarian Development, Ministry of Fisheries and Aquaculture, Ministry of Education) for the financial support.

RESUMO: Os consumidores têm exigido cada vez mais alimentos naturais e ausentes de resíduos medicamentosos. O objetivo deste estudo foi avaliar o extrato aquoso de caule de romã seco e in natura, sobre a inibição larval de Haemonchus spp. e Cooperia spp. provenientes de bovinos. Foram avaliados extrato aquoso de caule de romã (EACR) seca e in natura, controle negativo (água destilada autoclavada) e controle positivo (cloridrato de levamisol 0,05 $\mathrm{mg} / \mathrm{mL}$ ). Foram utilizados quatro $\mathrm{mL}$ de cada tratamento, e os resultados foram avaliados em triplicata, por meio de contagem de ovos por grama de fezes (OPG), cultura de larvas e contagem das larvas. A média de larvas desenvolvidas por grama de fezes foi submetida à transformação logarítmica Log. $(x+10)$. A contagem de OPG apresentou valor médio de 3.620 ovos, sendo identificadas na cultura de larvas de Haemonchus e Cooperia. EACR seca apresentou por meio da redução de larvas, eficácia efetiva de 92,29\% para Haemonchus e 96,97\% para Cooperia. In natura, este extrato apresentou $80 \%$ de eficácia sobre larvas de Cooperia, sendo considerado moderadamente efetivo, porém, para Haemonchus o mesmo não foi efetivo. Esses resultados são especialmente importantes para os sistemas orgânicos e agroecológicos de produção, que não permitem a utilização de parasiticidas químicos. Concluiu-se que a utilização de EACR seca apresentou potencial anti-helmíntico, podendo representar importante opção terapêutica natural. 
PALAVRAS-CHAVE: Agroecologia. Plantas Medicinais. Punica granatum Linn. Verminose.

\section{REFERENCES}

ATHANASIADOU, S.; KYRIAZAKIS, I.; JACKSON, F.; COOP, R. L. Direct anthelmintic effects of condensed tannins towards different gastrointestinal nematodes of sheep: in vitro and in vivo studies. Veterinary Parasitology, Netherlands, v. 99, p. 205-219, 2001. http://dx.doi.org/10.1016/S03044017(01)00467-8

BATATINHA, M. J. M.; ALMEIDA, G. N.; DOMINGUES, L. F.; SIMAS, M. M. S.; BOTURA, M. B.; CRUZ, A. C. F. G.; ALMEIDA, M. A. O. Efeitos dos extratos aquoso e metanólico de algaroba sobre culturas de larvas de nematódeos gastrintestinais de caprinos. Ciência Animal Brasileira, Goiânia, v. 12, p. 514-519, 2011. http://dx.doi.org/10.5216/cab.v12i3.3653

BLOIS, M. S. Antioxidant determination by the use of a stable free radical. Nature, London, v. 181, p. 11991200, 1958. http://dx.doi.org/10.1038/1811199a0

BRAND-WILLIAMS, W.; CUVELIER, M. E.; BERSET, C. Use of a free radical method to evaluate antioxidant activity. LWT-Food Science and Technology, Georgia, v. 28, p. 25-30, 1995.

http://dx.doi.org/10.1016/S0023-6438(95)80008-5

BRUNET, S.; MONTELLANO, C. M.; TORRES-ACOSTA, J. F.; SANDOVAL-CASTRO, C. A.; AGUILARCABALLERO, A. J.; CAPETILLO-LEAL, C.; HOSTE, H., 2008. Effect of the consumption of Lysiloma latisiliquum on the larval establishment of gastrointestinal nematodes in goats. Veterinary Parasitology, Netherlands, v. 157, p. 81-88, 2008. http://dx.doi.org/10.1016/j.vetpar.2008.07.013

CEZAR, A. S.; CATTO, J. B.; BIANCHIN, I. Controle alternativo de nematódeos gastrintestinais dos ruminantes: atualidade e perspectivas. Ciência Rural, Santa Maria, v. 38, p. 2083-2091, 2008.

D’ALMEIDA, T. N. Bem-estar animal x segurança alimentar. Higiene Alimentar, São Paulo, v. 19, p. 15-17, 2005.

DI MAMBRO, V. M.; FONSECA, M. J. V. Assays of physical stability and antioxidant activity of a topical formulation added with different plant extracts. Journal of pharmaceutical and biomedical analysis, Georgia, v. 37, p. 287-295, 2005. http://dx.doi.org/10.1016/j.jpba.2004.10.030

FAGBEMI, T. N.; OSHODI, A. A.; IPINMOROTI, K. O. Processing Effects on Some Antinutritional Factors and In vitro Multienzyme Protein Digestibility (IVPD) of Three Tropical Seeds: Breadnut (Artocarpus altilis), Cashewnut (Anacardium occidentale) and Fluted Pumpkin (Telfairia occidentalis). Pakistan Journal of Nutriticion, Sargodha, v. 4, p. 250-256, 2005.

FAO - Food and agriculture organization of the united nations. Food outlook: global market analysis, Rome, Italy, 121 p. Available at: <http://www.fao.org/docrep/015/al989e/al989e00.pdf>. (Acessed 09.05. 2012). 2012.

GOMES, P. Fruticultura brasileira, São Paulo: Nobel, 446 pp. 1972.

GORDON, H. M.; WHITLOCK, H. V. A new technique for courtin nematode eggs in sheep faeces. Journal of Council of Science and Industry Research in Australia, Melbourne, v. 12, p. 50-52, 1939.

HOSTE, H.; JACKSON, F.; ATHANASIADOU, S.; THAMSBORG, S. M.; HOSKIN, S. O. The effects of tannin-rich plants on parasitic nematodes in ruminants. Trends in Parasitology, Cambridge, v. 22, p. 253-261, 2006. http://dx.doi.org/10.1016/j.pt.2006.04.004 
JARDINI, F. A. Antioxidant activity evaluation of the pomegranate (Punica granatum, L.) hidroalcoholic extract at Caco-2 cell line. Food Science and Technology, Campinas, v. 27, p. 80-83, 2007.

http://dx.doi.org/10.1590/S0101-20612007000500014

JOSHI, B. R.; KOMMURU, D. S.; TERRILL, T. H.; MOSJIDIS, J. A.; BURKE, J. M.; SHAKYA, K. P.; MILLER, J. E. Effect of feeding sericea lespedeza leaf meal in goats experimentally infected with Haemonchus contortus. Veterinery Parasitology, Netherlands, v. 178, p. 192-197, 2011. http://dx.doi.org/10.1016/j.vetpar.2010.12.017

KEITH, R. K. The differentiation of the infective larval of some common nematode parasites of catle. Australian Journal of Zoology, Clayton South, v. 1, p. 223-23, 1953. http://dx.doi.org/10.1071/ZO9530223

KETZIS, J. K.; VERCRUYSSE, J.; STROMBERG, B. E.; LARSEN, M.; ATHANASIADOU, S., HOUDIJK, J. G. Evaluation of efficacy expectations for novel and non-chemical helminth control strategies in ruminants. Veterinery Parasitology, Netherlands, v. 139, p. 321-335, 2006.

http://dx.doi.org/10.1016/j.vetpar.2006.04.022

LANSKY, E. P.; NEWMANN, R. A. Punica granatum (pomegranate) and its potential for prevention and treatment of inflammation and cancer. Journal of ethnopharmacology, Einsteinweg, v. 109, p. 177- 200, 2007. http://dx.doi.org/10.1016/j.jep.2006.09.006

LIMA, W. C.; ATHAYDE, A. C. R.; MEDEIROS, G. R.; LIMA, D. A. S. D.; BORBUREMA, J. B.; SANTOS, E. M.; VILELA, V. L. R.; AZEVEDO, S. S. Nematóides resistentes a alguns anti-helmínticos em rebanhos caprinos no Cariri Paraibano, Brasil. Pesquisa Veterinária Brasileira, Rio de Janeiro, v. 30, p. 1003-1009, 2010.

LORENZI, H.; MATOS, F. J. A. (2ed). Plantas Medicinais no Brasil: Nativas e Exóticas. São Paulo, 2002.

MANIAN, R.; ANUSUYA, N.; SIDDHURAJU, P.; MANIAN, S. The antioxidant activity and free radical scavenging potential of two different solvent extracts of Camellia sinensis (L.) O. Kuntz, Ficus bengalensis $\mathrm{L}$. and Ficus racemosa L. Food Chemistry, Whiteknights, v. 107, p. 1000-1007, 2008.

http://dx.doi.org/10.1016/j.foodchem.2007.09.008

MARTÍNEZ-ORTÍZ-DE-MONTELLAN, O. C.; VARGAS-MAGAÑA, J. J.; CNUL-KU, H. L.; MIRANDASOBERANIS, R.; CAPETILLO-LEAL, C.; SANDOVAL-CASTRO, C.; HOSTE, H.; TORRES-ACOSTA, J.F.J. Effect of a tropical tannin-rich plant Lysiloma latisiliquum on adult populations of Haemonchus contortus in sheep. Veterinery Parasitology, Netherlands, v. 172, p. 283-290, 2010.

http://dx.doi.org/10.1016/j.vetpar.2010.04.040

MAX, R. A.; KASSUKU, A. A.; KIMAMBO, A. E.; MTENGA, L. A.; WAKELIN, D.; BUTTERY, P. J. The effect of wattle tannin drenches on gastrointestinal nematodes of tropical sheep and goats during experimental and natural infections. The Journal of Agricultural Science, Nottingham, v. 147, p. 211-218, 2009. doi: http://dx.doi.org/10.1017/S0021859608008368

MEDEIROS, R. D.; SANTANA, F. S.; LIMA NETO, J. F. Caracterização dos sistemas de produção: Horticultura orgânica no município de Areia Branca - SE e Produção de leite orgânico no município de Nossa Senhora da Glória - SE. Scientia Plena, Sergipe, v. 6, p. 1-5, 2011.

MINHO, A. P.; BUENO, I. C. S.; LOUVANDINI, H.; JACKSON, F.; GENNARI, S. M.; ABDALLA, A. L. Effect of Acacia molissima tannin extract on the control of gastrointestinal parasites in sheep. Animal Feed Science and Technology, Apopka, v. 147, p. 172-181, 2008.

http://dx.doi.org/10.1016/j.anifeedsci.2007.09.016 
MUPEYO, B.; BARRYA, T. N.; POMROYA, W. E.; RAMÍREZ-RESTREPOA, C. A.; LÓPEZ-

VILLALOBOSA,N.; PERNTHANERC, A. Effects of feeding willow (Salix spp.) upon death of established parasites and parasite fecundity. Animal Feed Science and Technology, Apopka, v. 164, p. 8-20, 2011. http://dx.doi.org/10.1016/j.anifeedsci.2010.11.015

NASCIMENTO, E. M.; FURLONG, J.; PIMENTA, D. S.; PRATA, M. C. A. Efeito anti-helmíntico do hidrolato de Mentha villosa Huds. (Lamiaceae) em nematóides gastrintestinais de bovinos. Ciência Rural, Santa Maria, v. 39, n. 3, 2009.

NODA, Y.; KANEYUKI, T.; MORI, A.; PACKER, L. Antioxidant activities of pomegranate fruit extract and its anthocyanidins: delphinidin, cyaniding, and pelargonidin. Journal of Agricultural and Food Chemistry, Münchv, 39, n. 3, 2009.en, v. 50, p. 166-171, 2002. http://dx.doi.org/10.1021/jf0108765

OLIVEIRA, L. M. B.; BEVILAQUAI, C. M. L.; MORAIS, S. M.; CAMURÇA-VASCONCELOS, A. L. F.; MACEDO, I. T. F. Plantas taniníferas e o controle de nematóides gastrintestinais de pequenos ruminantes. Ciência Rural, Santa Maria, v. 41, p. 1967-1974, 2011.

OTERO, M. J.; HIDALGO, L. G. Condensed tannins in temperate forage species: effects on the productivity of ruminants infected with internal parasites (a review). Livestock Research for Rural Development, Cali, v. 16, p. 1-9, 2004.

PEDRIALLI, C. A.; FERNANDES, A. U.; SANTOS, P. A.; SILVA, M. M.; SEVERINO, D.; SILVA, M. B. Antioxidant activity, cito- and phototoxicity of pomegranate (Punica granatum L.) seed pulp extract. Food Science and Technology, Campinas, v. 30, p. 1017-1021, 2010. http://dx.doi.org/10.1590/S010120612010000400028

PEREIRA, A. L. F.; VIDAL, T. F.; CONSTANT, P. B. L. Dietary antioxidants: chemical and biological importance. Nutrire - Revista da Sociedade Brasileira de Alimentação e Nutrição, São Paulo, v. 34, p. 231247, 2009.

ROBERTS, F. H. S.; O'SULLIVAN, J. P. Methods of egg couts and laval cultures for strongyles infest ing the gastrointestinal tract of cattle. Australian Journal of Agricultural Research, Sydney, v. 1, p. 99-102, 1950. http://dx.doi.org/10.1071/AR9500099

ROZWALKA, L. C.; LIMA, M. L. R. Z. C.; MIO, L. L. M.; NAKASHIMA, T. Extratos, decoctos e óleos essenciais de plantas medicinais e aromáticas na inibição de Glomerella cingulata e Colletotrichum gloeosporioides de frutos de goiaba. Ciência Rural. Santa Maria, v. 38, p. 301-307, 2008. http://dx.doi.org/10.1590/S0103-84782008000200001

SCZESNY-MORAES, E. A.; BIANCHIN, I.; SILVA, K. F.; CATTO, J. B.; HONER, M. R.; PAIVA, F. Resistência anti-helmíntica de nematóides gastrintestinais em ovinos, Mato Grosso do Sul. Pesquisa Veterinária Brasileira, Rio de Janeiro, v. 30, p. 229-236, 2010. http://dx.doi.org/10.1590/S0100736X2010000300007.

SOUZA, A. P.; RAMOS, C. I.; BELLATO, V.; SARTOR, A. A.; SCHELBAUER, C. A. Resistência de helmintos gastrintestinais de bovinos a anti-helmínticos no Planalto Catarinense. Ciência Rural, Santa Maria, v. 38, p. $1363-1367,2008$.

UENO, H.; GONÇALVES, P. C. Manual para diagnóstico das helmintoses de ruminantes, 4th ed. Japan International Cooperation Agency, Tokyo, 143 pp. 1998.

VIEIRA, L. S. Métodos alternativos de controle de nematóides gastrintestinais em caprinos e ovinos.

Tecnologia Ciências Agropecuárias, v. 2, 49-56 pp. 2008. 
WOOD, I. B.; AMARAL, N. K.; BAIRDEN, K.; DUNCAN, J. L.; KASSAI, T.; MALONE, J. B.; PANKAVICH, J. A.; SLOCOMBE, O.; TAYLOR, S. M.; VERCRUYSSE, J. World Association for the Advancement of Veterinary Parasitology (W.A.A.V.P.) second edition of guidelines for evaluating the efficacy of anthelmintics in ruminants (bovine, ovine, caprine). Veterinary Parasitology, Netherlands, v. 58, p. 181213, 1995. http://dx.doi.org/10.1016/0304-4017(95)00806-2

ZHISHEN, J.; MENGCHENG, T.; JIANMING, W. The determination of flavonoid contents in mulberry and their scavenging effects on superoxide radicals. Food chemistry, London, v. 64, p. 555-559, 1999. http://dx.doi.org/10.1016/S0308-8146(98)00102-2 